\title{
Testimonios
}

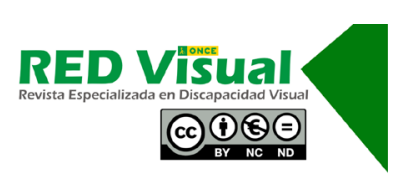

Recepción: 27-02-2021 Aceptación: 24-03-2021

\section{Vivencias de pandemia}

\author{
L. Quintas Rejo
}

Soy Lorena, y quiero aprovechar estas líneas para compartir con vosotros mis vivencias durante esta pandemia, que parece no tener un final. Sin embargo, quiero hacer gala del optimismo que me caracteriza y vamos a pensar que la vacuna nos hará la vida más fácil. Aunque el túnel es largo y tenebroso, puede que vislumbremos una pequeña luz a lo lejos para, así, no perder la esperanza. Vivo en un pequeño pueblo de la provincia de Orense y, a este escondido rincón del mundo, también ha llegado la covid. Pero os contaré la historia desde el principio.

Hace un año que vivíamos ajenos al inminente peligro, teníamos nuestras vidas y nuestras preocupaciones personales. Nunca habíamos hecho el ejercicio de reflexionar acerca del comportamiento cívico y comunitario que ahora escuchamos hasta la saciedad. Tan solo hacía poco más de un mes que se mencionaba el término covid-19 en las noticias, sin tan siquiera saber si era una palabra masculina o femenina. Sonaba lejos, estaba en China y no parecía un problema nuestro; ¿quién se imaginaba que viajaría 8000 km? Sin embargo, pronto llegó a Italia y las alarmas se dispararon: había aterrizado en Europa.

Recuerdo con nostalgia aquel 21 de febrero: estaba con mi familia pasando unos días en Roma, cuando empezó el caos. Primero, vimos en las noticias locales que iban cerrar un pueblo de Lombardía debido a la aparición del primer caso de covid. En aquellos días hacia tan buen tiempo en la capital italiana que la ciudad era un hormiguero de turistas; todos disfrutábamos de la magia de la ciudad sin ser conscientes del grave peligro que se avecinaba. Dos días después, los casos se multiplicaban en el norte y cerraron Lombardía, justo cuando regresábamos a casa. Ya en la comodidad de nuestro pueblo nos sentimos seguros de poder regresar sin problemas; si tan solo hubiéramos tardado un par de días más, nos hubiéramos quedado en Italia.

Quintas, L. (2021). Vivencias de pandemia. RED Visual: Revista Especializada en Discapacidad Visual, 77, 345-347. https://doi.org/10.53094/VTQH7594. 
Europa empezó a temblar y el mundo volcó su mirada en Italia. Unos nuevos vocablos surgieron con gran fuerza: confinamiento domiciliario, mascarillas, distanciamiento social, cuarentena... iDaba miedo! Desgraciadamente, en pocos días estaba en España y en el mundo entero; había llegado para quedarse.

Un año después sigo escuchando con claridad las palabras del presidente, mientras explicaba que el 15 de marzo entrábamos en confinamiento total. Mi cerebro no era capaz de procesar la información, me parecía una situación surrealista; ¿en serio esto era posible? Pues... al parecer sí. Tardé días, me atrevería a decir varias semanas, en darme cuenta del alcance de todo ello. Tendría que parar mis exposiciones, no podría vender en un tiempo mi artesanía, no podríamos celebrar el 90 aniversario de mi abuelita, pasaría mucho tiempo hasta que volviéramos a salir de casa, no quedaría con mis amigos en una buena temporada, no haría el ansiado viaje a California, ni la boda de mi mejor amiga, ni la visita semanal al fisio, ni las clases de idiomas... iTodo se había parado!

Desde mi perspectiva, el confinamiento de marzo no fue tan terrible como para quienes viven en la ciudad. Me siento afortunada de vivir en un entorno rural, en una casa con finca, perros y gallinas; un entorno más llevadero para soportar esta difícil situación. En este sentido, la carga psicológica fue mucho menor que si viviera en un piso. A pesar de ello, cada mes que pasa en esta pandemia se hace más duro y cansado, y un año después ya estamos todos agotados. Dejé mi ritmo diario de tareas cotidianas, pasé meses sin ver a mis amigos y familia. Aunque vivo con mis padres y hermana, también es necesaria la interacción social con los demás para salir de la monotonía. Como la mayoría, me convertí en adicta a las videollamadas, ese pequeño universo que te acerca a la persona querida. Pero no sé hasta cuándo será suficiente.

Durante este año, nos hemos acostumbrado al silencio y la soledad como factores consecuencia de las restricciones. Pero cuando se prolonga tanto en el tiempo, resulta abrumador; echo de menos el sonido de los coches, las voces de la gente a lo lejos, las risas de los niños en el parque... A veces, siento que estamos solos en el mundo. Recuerdo cómo mi padre venía asustado del trabajo; al llegar a casa, nos contaba que Orense parecía una ciudad fantasma. Y encima de todo este caos, está el pánico al contagio, la impotencia que genera no saber dónde está o qué va pasar; esa angustia llega al alma y te deja sin capacidad de actuación.

Quintas, L. (2021). Vivencias de pandemia. RED Visual: Revista Especializada en Discapacidad Visual, 77, 345-347. https://doi.org/10.53094/VTQH7594. 
Al principio, parecía que el virus era de ciudad, pero, con cada nueva ola, se introduce más en las poblaciones rurales. Ahora es tu vecino quién está contagiado, ahora es tu pueblo el que está cerrado perimetralmente, ahora es en tu casa la cuarentena. Y lo peor es que no hay lugar en la Tierra hacia dónde escapar.

Afortunadamente, y hasta el momento, no me he contagiado, pero ello no significa que mañana no lo esté. Sin embargo, todas mis esperanzas están en la vacuna; no veo el momento de recuperar mi vida anterior y poder seguir disfrutando de las oportunidades que se presentan.

\section{Lorena Quintas Rejo}

Quintas, L. (2021). Vivencias de pandemia. RED Visual: Revista Especializada en Discapacidad Visual, 77, 345-347. https://doi.org/10.53094/VTQH7594. 